Volume 3 Issue 1 (2019) Pages 170 - 182

Jurnal Obsesi : Jurnal Pendidikan Anak Usia Dini

DOI: $10.31004 /$ obsesi.v3i1.140

\title{
The Implementation of Nature-based Learning Models to Improve Children's Motor Skills
}

\author{
Aulia Annisa $^{1 \bowtie}$, Panggung Sutapa ${ }^{2}$ \\ Pasca Sarjana Universitas Negeri Yogyakarta
}

\begin{abstract}
The balance between fine and gross motor skills of children is important to be optimally stimulated. The purpose of this study was to determine the effectiveness of nature-based learning models in improving children's motor skills. This study used a quantitative method with a subject of 45 children aged 4-5 years in 3 kindergartens in Sleman Regency. The study design used one group pretest posttest with 3 treatments each. Data collection techniques using observations and interviews were analyzed using descriptive quantitative and the effectiveness was analyzed using the $\mathrm{T}$ test. The results showed that nature-based learning effectively increases motor skills because by using the five senses, children have learning experiences through play, according to age needs, using objects concrete, up to challenging activities. Nature-based learning model can be an innovation that can be used as material for further research related to cognitive, language, art, and social emotional in children.
\end{abstract}

Keywords: Learning Model; Nature Based Learning; Motor Skills

\begin{abstract}
Abstrak
Keseimbangan antara keterampilan motorik halus dan kasar anak penting untuk distimulasi secara optimal. Tujuan dari penelitian ini adalah untuk mengetahui efektivitas model pembelajaran berbasis alam dalam meningkatkan keterampilan motorik anak. Penelitian ini menggunakan metode kuantitatif dengan subjek sebanyak 45 anak usia 4-5 tahun di 3 TK yang berada di Kabupaten Sleman. Desain penelitian menggunakan one group pretest posttest dengan masing-masing 3 kali perlakuan. Teknik pengumpulan data menggunakan observasi dan wawancara yang dianalisis menggunakan deskriptif kuantitatif dan efektivitas dianalisis menggunakan uji T. Hasil penelitian menunjukkan bahwa pembelajaran berbasis alam efektif meningkatkan keterampilan motorik karena dengan menggunakan panca inderanya, anak memiliki pengalaman belajar melalui bermain, sesuai dengan kebutuhan usia, menggunakan benda konkrit, hingga kegiatan yang menantang. Model pembelajaran berbasis alam dapat merupakan inovasi yang dapat menjadi bahan penelitian selanjutnya terkait kognitif, bahasa, seni, dan sosial emosional pada anak.
\end{abstract}

Kata Kunci: Model Pembelajaran; Pembelajaran Berbasis Alam; Keterampilan Motorik.

@ Jurnal Obsesi Prodi PG-PAUD FIP UPTT 2019

$\triangle$ Corresponding author:

Address : Yogyakarta, Indoenesia

Email : auliaannisa.2017@student.uny.ac.id

ISSN 2356-1327 (Media Cetak)

ISSN 2549-8959 (Media Online) 


\section{INTRODUCTION}

The beginning of the 21st century, known as the millennial era, immediately changed all components of life including the world of children. Children who grow and develop in this century indirectly have a very complex pattern of development seen from all kinds of aspects of development. The age known as this technological era gradually began to undermine the world of education. As a result, understanding and using technology that is not on target causes some misunderstanding in integrating it with learning in children. One example of the change that is closest to children is motor activity. Motoric activity is currently packaged in such a way that what initially aims to facilitate activities is to turn off creativity. As emphasized by (Dwirahmah, 2013) that the creative nature of children will emerge if there is a vehicle that provides space for children to develop.

The development of the main motor skills that occur during early childhood revolves around the mastery and control of the environment which later familiar psychologists call this period as "the age of explorers" (Sujiono, 2010). This labeling shows that children want to know the state of their environment, the procedures of the mechanism, their feelings and try to be part of the environment itself. This will enrich children's experiences and can increase their knowledge naturally. Children learn to experiment, explore, and investigate the surrounding environment. As a result, children will be able to build a knowledge that will become a new experience and can be used in the future.

In learning, if the child only sees and hears the child receives only a little of what he has seen that is reaching $50 \%$. Whereas if children experience and are directly involved in it the level of acceptance is $80 \%$ (Silberman, 2009). At the age of $0-8$ years there is an increase in movement coordination and body balance which is quite fast. Increased movement coordination and accompanied by greater leg and hand leverage, make children more able to use their strength in doing physical activities. This is important as a process of optimizing child development, especially the physical aspects of the motor (Alim, 2015).

But in reality, it is not easy to change the habits and behaviors that have grown down the lowest which are then believed to be the most effective things to stimulate the development of children with diverse characteristics. One thing that should not be forgotten by anyone involved in the world of children, both parents and educators, is that children are born and grow with their respective potentials and characteristics. Automatically, everything that is done to stimulate all aspects of a child's development does not necessarily use the same methods and strategies between one child and another child. Nature-based learning in early childhood involves children in the process of scientific thinking, children learn to understand phenomena, answer questions, find more information about something and question conclusions obtained by other children (Sujiono, 2007). These things have now been replaced by the activity book function which is the main subject in children's activities. Children lack the opportunity to carry out the process of scientific thinking in learning.

Utilization of the natural environment that is less than optimal in supporting children's motor development stimulus also produces several studies that show that today's children lack sufficient motor skills to maintain health. This alarming trend may reflect changes in children's behavioral activities in recent 
172 | The Implementation of Nature-based Learning Models to Improve Children's Motor Skills

decades and may reflect an inactive lifestyle and low levels of physical activity (Castetbon \& Andreyeva, 2012; Iivonen \& Sääkslahti, 2013). From several kindergartens in Sleman regency, some have quite beautiful school yards with lots of trees and plants that make the school environment look more beautiful. But unfortunately, existing natural facilities are not used optimally by educators to stimulate child development.

In addition to the management of the school environment, the learning model in schools is also an obstacle because they still use conventional models so that early childhood is bored and less interested in the lessons delivered by educators. This makes children less explored with learning resources that exist in the environment, especially the natural environment (Wulansari \& Sugito, 2016). One source of learning that is very close to children is sand and water. Some people still consider sand and water to be a dirty and less effective game used for children. But apparently, gross motor development occurs when children play sand and water like when lifting sand and water repeatedly children, develop strength, balance and endurance. Not only that, fine motor development also occurs when children play wet sand. Children channel their imagination through various activities using sand and water such as making pictures with their fingers or with wood or twigs, printing palms on sand to decorate various shapes with prints. This should be considered because when the child becomes dirty and wet while playing sand and water, that's where the child learns and explores fully with the media so that the child will find new knowledge and concepts on their own through playing sand and water (Yusnira, 2015).

Early childhood education requires a fun learning in accordance with the way children learn. Therefore, in activities to stimulate children's motor development, a learning model that is appropriate to the needs of the child is needed while still taking into account the child's safety and comfort so that the child's ability to develop according to his age stage The conventional learning model which is only in the form of drawing or coloring activities using paint and stationery as if binding on motoric activities in a domain that is too narrow. Though children's motor activities can be integrated with natural materials and carried out in the natural environment. Based on the background above, the researchers are interested in conducting research related to the effectiveness of the implementation of nature-based learning models (Wulansari \& Sugito, 2016).

The Nature Based Learning Model (PBA) is a learning model that has the principle of learning about nature, learning to use nature, and learning with nature. Learning about nature means the PBA Model learns the concepts of nature as learning material. Learning to use nature means the PBA Model uses learning resources that are in nature. Whereas, learning with nature means the PBA Model where to learn using the natural environment (Wulansari \& Sugito, 2016). PBA models are developed to optimize all potential children including motor skills. Learning activities are carried out by identifying the natural environment. The PBA model supports the development of basic motor movements freely with nature. The combination of real and academic learning about nature is an experience for children's learning. The motoric activity carried out by children by involving nature indirectly connects the child's long experience with new experiences about nature which are an important part of learning PBA Model. 
Implementation of the PBA Model adopts pembelajaran (Zurek \& Torquati, 2014)which are summarized, namely eliciting, inferential quotiestioning, prediction, focus, give hint, providing material, feedback, generalization, and conclution. Eliciting is arousing the child's response, inferential quotiestioning is a suggestion to the child to use the existing facts, prediction is the encouragement to the child to guess what will happen next, focus is to focus the investigation on the narrower, give hint is the help of the child to find something, provide material for the provision of tools to support investigation, feeback is feedback given by the teacher to the findings, generalization is to draw findings to things that are more general, and conclusions are conclusions from children's findings and learning outcomes in investigation. PBA Model Planning is emphasized in the making of themes and plans for implementing sub-theme learning (RPPST). The chosen theme is a theme that supports nature-based learning. Whereas for the purpose of natural sustainability adapted to the sub-themes developed. RPPST accommodates one goal for the sustainability of the natural environment to be introduced to early childhood.

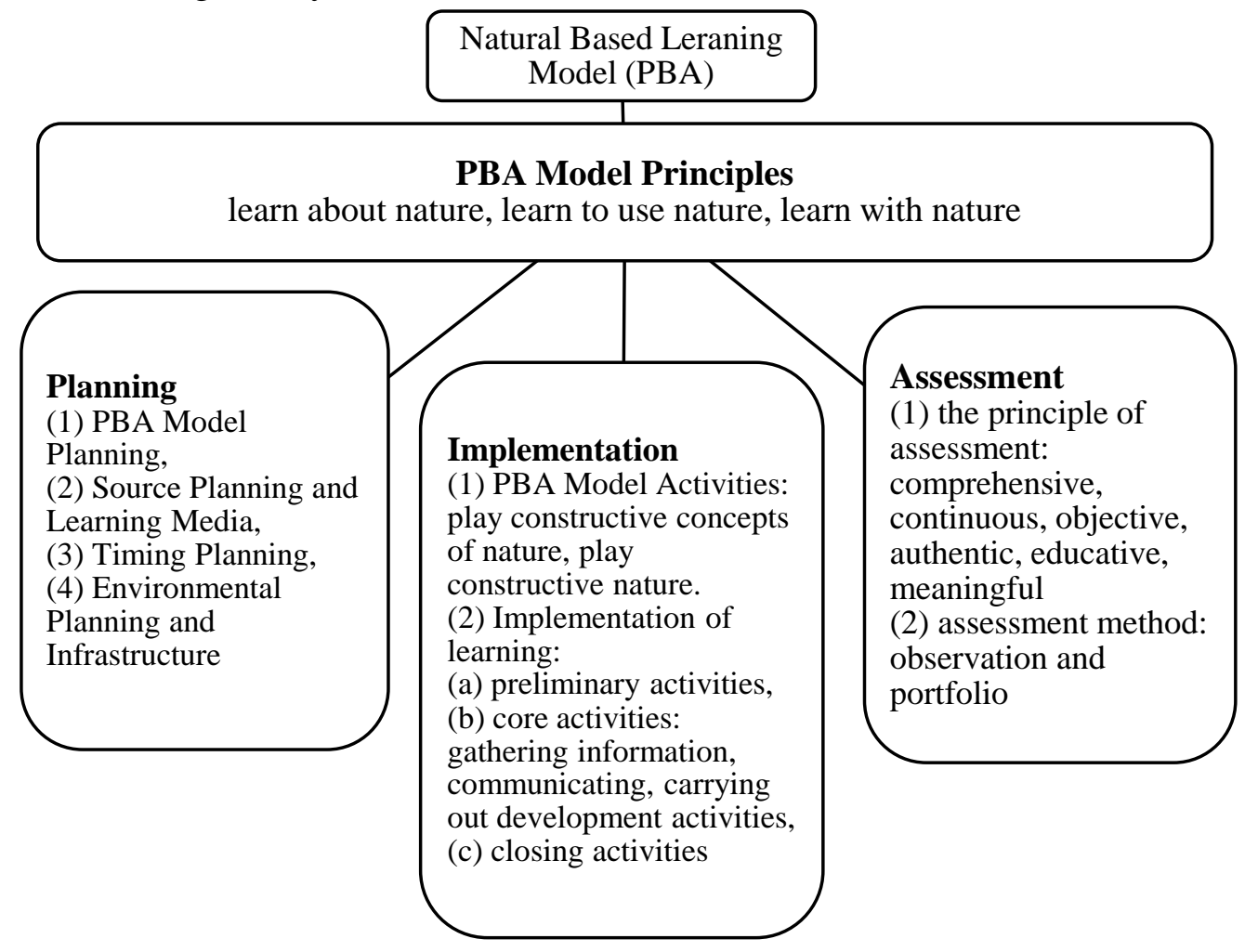

Figure 1. Conceptual Concept of Nature Based Learning Scheme (Wulansari \& Sugito, 2016)

The main activities in this PBA Model adopted from (Moore \& Cooper, 2014) are natural loose parts, natural constructionism, and natural play structure. Natural loose parts are activities that manipulate small natural objects around.
Natural constructionism is an activity of constructive thinking about natural objects and the natural play structure of activities to play construction using natural materials. Assessment of the PBA Model is emphasized in the assessment of children's 
174 | The Implementation of Nature-based Learning Models to Improve Children's Motor Skills

learning processes, this is in accordance with the Assessment of Effective Environment developed by (Wiliam, 2010) from the results of research that early childhood assessment must be seen from the learning process. Planning for PBA models is emphasized in making themes and plans for implementing daily learning (RPPH). The theme chosen is a theme that supports nature-based learning. Whereas for the purpose of natural sustainability adapted to the sub-themes developed. RPPH accommodates one goal for the sustainability of the natural environment to be introduced to early childhood.

The assessment was carried out to find out the results of learning activities arranged in the syntax of the PBA Model. The principle is (1) comprehensive means that the assessment is carried out on all aspects of child development, namely religious and moral values, language, cognitive, physical motor and social emotional. Thus, it can be seen that the progress of the child's development as a whole is experiencing an increase or a constant. (2) Continuity, namely the assessment process is carried out continuously using the right methods and instruments. (3) Objectives, meaning that children's development assessments are carried out in accordance with existing conditions (objectivity principle).

Authentic, meaning the assessment is carried out naturally in accordance with the daily conditions of the child which is integrated with the learning process. (5) Educative, for the purpose of changing behavior for the better, the assessment should contain an educational element so that it can educate both children, educators, parents and children. (6) Meaningfulness, meaning the results of the assessment are not just documents that must be completed at the right time but also must be meaningful or have meaning. While the assessment method used in assessing children's development uses observation, checklist, performance, anecdotes, interviews, and portfolios.

\section{METHODOLOGY}

This study uses a quantitative methodology that is defined as a form of research based on data from empirical realities systematically that can be measured by numbers. The time of the research was conducted in September located in 3 kindergartens in the sleman district of Yogyakarta. The kindergarten involved in this study were the UGM Mosque Kindergarten, Karangmalang ABA Kindergarten and Salman Alfarisi TK 2. The sample selection method used purposive sampling, namely nonprobability samples selected based on population characteristics and research objectives. The choice of research location is based on certain criteria, namely having lots of plants around the school and having trees and courtyards that are wide enough for children to play. At ABA Karangmalang Kindergarten also has a page containing children's playground equipment. However, there is little difference in the location which has limited land and the position of the school on the roadside. Based on these characteristics, the subjects in this study were 45 children aged 4-5 years in Sleman Regency with the criteria mentioned.

To determine the effectiveness of nature-based learning models in improving motor skills in children, researchers applied a research design using one group pretest posttest design by applying each treatment 3 times at the pretest and posttest. Data collection techniques were carried out using observations and interviews with motor activities for several weeks which were then analyzed using $\mathrm{T}$ 
test. Data collected in the form of relevant documents such as the implementation plan of learning. In addition, data collection is also done through interviews with teachers and parents about the learning model that is applied until the problems that occur are related to children's motor skills. Data is also obtained through classroom observations, including the arrangement of classrooms, existing facilities and infrastructure in the classroom, to learning media that support stimulation of child development. The collected data was then analyzed using quantitative descriptive techniques with design one group pretest-posttest design. The measuring instrument used in this study is an observation guide that is measured based on indicators of children's motor skills.

Table. 1. Pretest-Posttest Group Design

\begin{tabular}{|c|c|c|c|}
\hline Group & Pretest & Treatment & Posttest \\
\hline Eksperiments & $\mathrm{O} 1$ & $\mathrm{X}$ & $\mathrm{O} 2$ \\
\hline
\end{tabular}

Source: Sugiyono, 2011

\section{RESULT AND DISCUSSION}

The activities of motor skills both fine motor and gross motoric performed at TK entered into the opening activities. Before entering the classroom, children are lined up in and then do gymnastics every morning with a duration of approximately 7 minutes. After that the child is allowed to enter the class alternately and orderly. Just like kindergarten in general, classroom learning uses centers and classrooms designed to use chairs and chairs. This is intended to make it easier for children to move and feel free to do activities that they like. Entering the initiation activities, the teacher gives 3 activities that must be completed by the child in one day. Activities chosen by the teacher based on what aspects will be developed.
The activities of motor skills carried out in core activities still use conventional models, namely children are required to write, color, draw, and other activities that make children less active. Several times the teacher applied the project based learning model to stimulate children's fine motor skills such as buttoning clothes, meronce, making mats, etc. In core activities, not all children feel at home lingering in activities that are monotonous and less challenging for children. learning activities carried out indoors also indirectly cause children to get bored and bored so they are less interested in learning activities.

The game equipment in the classroom is indeed quite a lot, except that children are allowed to play when they have completed their assignments. This sometimes makes children upset and feel bored so that the results of child-made performance are not done optimally. There are 2 teachers who are in the class for each class with 15 children. Parents of children also do not wait as long as school children, only come when morning and then pick up when afternoon or evening.

From the three schools where the research was conducted, TK UGM Mosque and TK Salman Alfarisi 2 had a pretty beautiful school yard with lots of trees and plants that made the school environment look more beautiful. The advantage that children get from being in a natural learning environment is that children can automatically be more free to carry out physical motor activities they want to do. A natural environment also brings positive value in terms of the peace of mind of children when playing. other than that, the natural environment is also one of the factors that support children to learn through concrete objects. 
Whereas TK ABA Karangmalang only has a page that contains children's game tools. due to limited land and the position of schools located on the roadside, teachers and parents must be more careful in increasing their supervision of children. The playing field is also limited, namely from the front of the school to the fence, which is mostly covered by ceramics and stone. This also affects the playing pattern of children who are used to playing in a clean place. So that when taken to a natural and free place, not all children want to play especially when the place is not sterile.

\section{Result}

The observations show that (1) learning activities use a lot of classrooms, (2) motoric activities of children outside the room are limited to certain times, (3) children are bound to tasks resulting in limited children's time to play, (4) underutilized natural environment for stimulate children's motor skills, (5) not all children want to play outdoors, (6) learning activities are too monotonous so that the child's time is only done in the classroom. This fact shows that children need a new learning model that can give children the freedom to move, do activities they like, and choose their own playing environment that children enjoy both indoor and outdoor.

One of the new facts found in the field is that the TK of the UGM Mosque implements a full day school system which is currently experiencing many pros and cons. The pro said that full day school can help working parents. That is, parents can focus on working while children's activities can be controlled by the school. While the education experts who contradicted this policy assessed that the application of this full day school was a form of error in addressing education and schooling. As if education is synonymous with school, even though the true meaning of education is far wider. Education can be done at home, school, and in the community. The relevance of the full day school system applied by schools with nature-based learning lies in the absence of differences in the patterns of stimulation given to children. Schools that are the same as the less optimal management of the natural environment do not have any impact on the child even though the child is in school all day. Thus, school is only one element in education. Many empirical evidence shows that successful people are not only academically good people who are good at school, but who have good life skills.

In order to optimize the stimulus for aspects of child development, the researchers conducted several activities that involve children plunging directly to interact with nature. Motor activity is an activity that is rarely done by children, so many children are interested in trying to join in the game. This learning model is designed not to force the child to join in, but the teacher still encourages each child to play. at the beginning of the activity, the teacher also explains in advance what activities the child will do, where they do it, how the process, to what materials and infrastructure are used to play. the teacher's strategy that does not impose the wishes of this child was responded to well by the child. finally there are only a few children who live in the class because they don't want to play outdoors.

Activities carried out related to stimulation of motoric skills in children were categorized into fine motor activities and gross motor skills. The fine motor activities include doing crafts: cutting leaves, fruits and vegetables with scissors, glue, kneading, archery, weaving, meronce, playing with stones, wood or the like, building sand towers or building 
blocks, dressing dolls or small figures using natural material accessories. Whereas gross motoric activity carried out by children is climbing branches and trees, running around, playing catching and chasing, playing hide and seek, playing outside, for example: in the garden, in sand dunes, in playgrounds, swimming to playing with various kinds of balls.

Tabel 2. Motor Activity by Category

\begin{tabular}{|c|c|c|c|c|c|}
\hline \multirow{2}{*}{ Item } & \multicolumn{3}{|c|}{ Fine Motor } & \multicolumn{2}{|c|}{ Gross Motor } \\
\hline & Crafts & Building & Toys & Outdoor Games & Outdoor Sports \\
\hline Fine Motor Activity & & & & & \\
\hline $\begin{array}{l}\text { 1. does handcrafts: cuts things out } \\
\text { with scissors, glues, kneads }\end{array}$ & 75 & .0 & 30 & - & - \\
\hline $\begin{array}{l}\text { 2. paints or sketches with a pencil } \\
\text { or brush, etc. }\end{array}$ & 65 & $0^{.1}$ & 10 & - & - \\
\hline $\begin{array}{l}\text { 3. ties knots, bows, weaves, threads } \\
\text { beads }\end{array}$ & 75 & $2^{.1}$ & 10 & - & - \\
\hline 4. plays with lego, blocks or similar & 50 & $5^{.7}$ & 07 & - & - \\
\hline $\begin{array}{l}\text { 5. builds towers or the likes with } \\
\text { building blocks }\end{array}$ & 35 & 5 & 08 & - & - \\
\hline $\begin{array}{l}\text { 6. plays with small toys, such as } \\
\text { small figures (e.g. toy soldiers) }\end{array}$ & 12 & $0^{.1}$ & 80 & - & - \\
\hline $\begin{array}{l}\text { 7. plays with medium-sized toys, } \\
\text { for example, stuffed toys }\end{array}$ & 35 & .5 & 75 & - & - \\
\hline 8. dresses up dolls or small figures & 60 & $5^{.2}$ & 65 & - & - \\
\hline Gross Motor Activity & & & & & \\
\hline 1. Climbs & & - & & .79 & .20 \\
\hline $\begin{array}{l}\text { 2. runs around, plays catch and } \\
\text { chase }\end{array}$ & & - & & .78 & .30 \\
\hline 3. plays hide and seek & & - & & .70 & .15 \\
\hline $\begin{array}{l}\text { 4. plays outside, for example, in the } \\
\text { garden, in the sandpit, at the } \\
\text { playground }\end{array}$ & & - & & .68 & .25 \\
\hline 5. goes swimming & & - & & .10 & .85 \\
\hline 6. rides a scooter & & - & & .36 & .67 \\
\hline $\begin{array}{l}\text { 7. plays with a ball, soccer ball, } \\
\text { table tennis, etc. }\end{array}$ & & - & & .15 & .70 \\
\hline
\end{tabular}

After doing motor activities for 4 weeks with a frequency of 3 times a week, the results showed that children began to actively use their natural environment as a playground. Some children who initially don't want to play outside the room finally want to come into play because they see the response from their friends after playing outside. The following data show that some fine and rough motor activities have been shown to be effective in improving children's motor skills. fine and rough motoric activities are categorized again into several aspects, namely handicrafts, buildings, toys, outdoor games and outdoor sports.

The instrument of data collection uses 15 items of statements that have been validated by several experts. It takes a normal curve to see an increase in a child's 
178 | The Implementation of Nature-based Learning Models to Improve Children's Motor Skills

motor skills within 3 weeks. The assessment scale uses only 3 categories, namely not meet (low), partially meet (average), and fully meet (high).

$$
\begin{aligned}
\bar{x} & =(\text { Score } \min +\text { score } \max ) / 2 \\
& =(15+45) / 2 \\
& =30 \\
\text { SD } & =(\text { Max score }- \text { score } \min ) / 6 \\
& =45 / 6 \\
& =7,5
\end{aligned}
$$

\section{Category:}

$\begin{array}{ll}\text { Not meet }(\text { Low }) & =>25 \\ \text { Partially meet (Average) } & =25-35 \\ \text { Fully meet (High) } & =45<\end{array}$

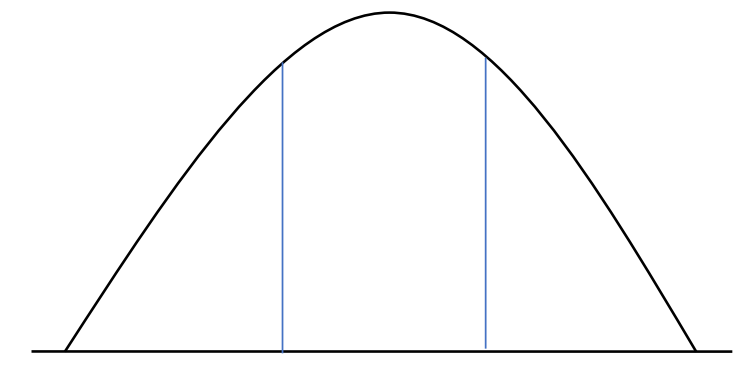

$$
15
$$<smiles>C[Hg]C</smiles>

\section{5}

K1

$\mathrm{K} 2$

K3

not Meet partially Meet fully Meet

Figure 2. Curve of Normality

Various motor activities carried out by children have certain advantages and disadvantages in each category. Data from the research show that, one motor activity is only superior and is characteristic of one category, whether it is fine motor or gross motoric. If educators and parents want to optimize fine motor skills as well as gross motor skills at the same time, it takes practice and routine motor activities to be interspersed between fine motor activity and gross motoric activity. The initial value of a child's basic skills is quite low. As seen on the normal curve above with 3 categories of child motor skills, basic skills of children before being given a relatively low nature-based learning model that is 15 points. While the average value is 30 and the highest value of children's ability after being given treatment is 45 and above. The experimental class data for more details are presented in the table below.

Table 3. Description of Experimental Class Data

\begin{tabular}{cccccc}
\hline Eksperim & $\begin{array}{c}\text { Pret } \\
\text { ent Class }\end{array}$ & $\begin{array}{c}\text { Postt } \\
\text { est }\end{array}$ & $\begin{array}{c}\text { Avera } \\
\text { ge }\end{array}$ & $\begin{array}{c}\text { est } \\
\text { Scor } \\
\text { e }\end{array}$ & $\begin{array}{c}\text { High } \\
\text { est } \\
\text { Score }\end{array}$ \\
\hline Week 1 & 17,6 & 23,1 & 20,4 & 791 & 1043 \\
\hline Week 2 & 22,3 & 30,7 & 26,4 & 1002 & 1379 \\
\hline Week 3 & 34,6 & 42,6 & 38,6 & 1557 & 1919 \\
\hline
\end{tabular}

Based on data accumulated in the form of the value of the pretest and posttest of a child's motor activity, it was found that there was a significant increase every week. In the first week, if guided by the normal curve, children's motor skills are still included in the low category, which is an average of only 20.4. Then began to increase children's motor skills in the second week. The average motoric skills of children reached a value of 26.4 , which means it belongs to the medium category. This is a fairly rapid development. The average data on motoric skills of children in the week when it was very satisfying was 38.6 which belonged to the high category. This shows that the implementation of nature-based learning models succeeded in increasing motor skills of 45-year-olds. 


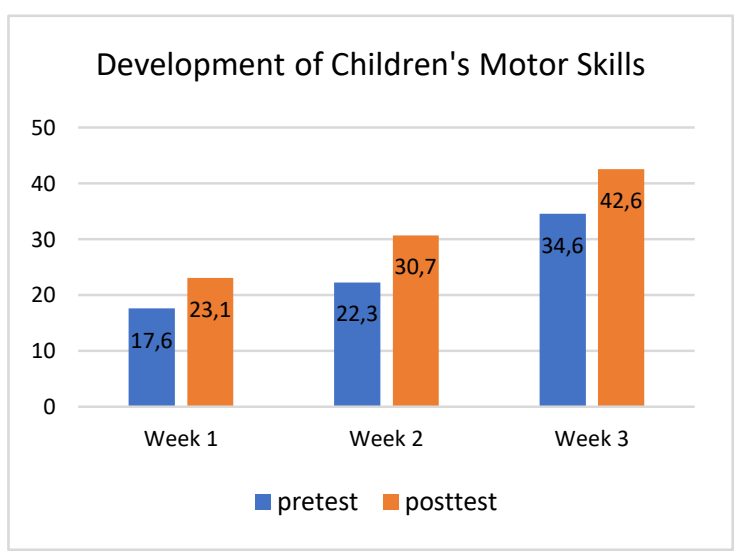

Figure 3. Chart of Development of Children's Motor Skills

The results of observations made also showed that basically all children like to learn new things related to nature. It's just that it takes time to adapt and leave the habit with learning that is monotonous and too dictates the wishes of children. Of the 45 children from 3 kindergartens involved in the study, it was found that in the first week $1 / 3$ of the children wanted to join the game outside the classroom using natural materials. This is because children prefer to do outdoor activities. In the following week, children's interest in motor activities in the natural environment increased. This is seen from almost $80 \%$ of the number of children who want to join in participating in motoric activities with nature. After being interviewed, it turned out that the child was interested in doing outdoor activities because he saw his friend who was always happy after playing from outside. Then in the last week of the study, 40 children were willing to play outside the classroom and do motoric activities with nature. 5 other children who refused to play outdoors with Alama due to parents being too sensitive to forbid children to play dirty and children who really preferred to play in class.
Table 4. Test of Normality

\begin{tabular}{lcccccc}
\hline & \multicolumn{3}{c}{$\begin{array}{c}\text { Kolmogorov- } \\
\text { Smirnov }\end{array}$} & \multicolumn{3}{c}{$\begin{array}{c}\text { Shapiro- } \\
\text { Wilk }\end{array}$} \\
\cline { 2 - 7 } & Statistic & df & Sig. & Statistic & df & Sig. \\
\hline Pretest &, 093 & 45 &, $200^{*}$ &, 949 & 45 &, 480 \\
Posttest &, 134 & 45 &, 410 &, 898 & 45 &, 100 \\
\hline *. This is a lower bound of the true significance. \\
a. Lilliefors Significance Correction
\end{tabular}

Based on the results of the significance of the pretest and posttest data contained in the above table, it was found a significance of 0.200 which means greater than 0.05. This shows that the data is normally distributed. Furthermore, to test the effectiveness of nature-based learning models, it was analyzed using paired $\mathrm{T}$ Tests.

Table 5. Paired Sample T Tests

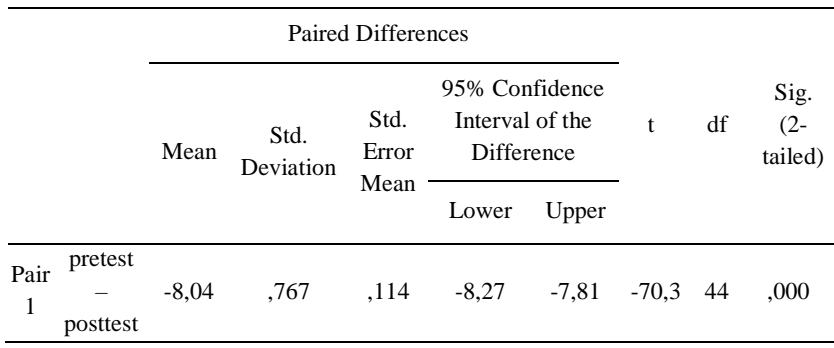

The results of the calculation of the ttest using SPSS Version 22. The results of the pretest and posttest have a value of $p=$ $0,000<0,05$, then $\mathrm{Ho}$ is rejected (Ha accepted). These results indicate a significant increase in pretest and posttest activities because of the influence of nature-based learning models. These results indicate that there is an effect of using natural-based learning models to improve children's motor skills.

\section{Discussion}

Based on the results of the study by implementing a nature-based learning model for children, it can be stated that nature-based learning models effectively improve fine motor and gross motor skills of children. The principle of nature-based learning, which is learning about nature, 
learning to use nature and learning with nature, which is then adapted to motor activities, has a special attraction for children. Children can be themselves and are free to choose what activities they like through this learning model. The following is an explanation related to the results of the study.

First, children learn through playing. All the things that make a child love are something that is basically a characteristic and need for a child. Playing is an important part that cannot be ruled out in the process of child development. Whatever type of game children do, there are always ways that make children feel free and find what children want. This is consistent with what is said (Samuelsson, Carlsson, Samuelsson, \& Carlsson, 2008; Anderson-McNamee \& Science Agent, Cascade County, 2010; Jackman, 2011; Huang, 2003) that children learn through play. Conventional learning models that seem to limit the desires and creativity of children should be avoided for optimization of child development. Therefore, the nature-based learning model that is designed in accordance with the characteristics and needs of children is very effective applied as a form of efforts to optimize child growth and development.

Second, children learn according to their age and individual abilities child. mentioned in (NAEYC, 2009) that children have different chronology of mastery of development in the same age and have different speeds in understanding an experience. This is clear enough to prove that every child is different from their potential and characteristics. There is no need to impose children's abilities in accordance with the standards possessed by educators and parents because each child's children have their own standards to be said to be successful. Therefore, the nature-based learning model is very supportive for children to carry out motor activities according to their needs and abilities. One thing that is also important to hold in the process of child development is the selfishness of educators and parents to optimize aspects of child development in accordance with their wishes.

Third, children learn through concrete objects. Learning to use natural materials as one of the principles of a nature-based learning model strongly supports children to learn to use concrete objects. All natural materials used by children to learn and play are objects that are not far away from the reach of children so they are easy to find. With the existence of concrete objects, children can use all five senses to be active, which is also important as a manifestation of the stimulation of child development. This is consistent with (Miller, 1996) statement that children learn through interaction with learning tools.

Fourth, child-centered learning. Activities that are in the nature-based learning model are indirectly designed so that children who are active in the learning process. The teacher's role is only to oversee and provide clear direction and guide the child to remain in the right behavior. Although children are free to choose the activities they want to do, but the teacher still plays an important role in terms of directing and guiding during the process of the activity. This is so that the child is not mistaken about what he sees and learns. The characteristics of children's learning are in accordance with (Ridgway \& Quinones, 2012) that educators are in charge of guiding, suggesting and expanding but not to control or command.

Fifth, children get direct experience through interesting learning. This is supported by (Miller, 1996; NAEYC: 2009) statement that children learn through integrated experience. Therefore, natural 
material based learning models are packaged in such a way that is attractive to children. interesting activities make children happy to carry out activities without the need to be forced or feel threatened because of fear.

Sixth, children go through the level of development by carrying out challenging activities. Children are individuals who are full of ambition and always feel curious, especially when something new is found. Based on these characteristics, nature-based learning models are designed so that children are able to explore, discover new things, practice analyzing objects, and conduct experiments with all available natural facilities. Challenging activities such as climbing, jumping, etc. make the soul of a child called to dare to take risks to fulfill the desire to solve challenges. (Dolya, 2009; Bodrova \& Leong, 2013) state that children try to get past their level of development through challenging activities. Challenging activities are given so that children are interested in going through the next stage of development.

The implementation of natural based learning models is designed to improve motor skills in early childhood so that they try to provide learning services that are appropriate to the needs of early childhood. Educators and parents also will not run out of ideas in making an activity program to improve children's motor skills because nature has been very helpful as a place, tool and media to stimulate child development.

\section{CONCLUSION}

Nature-based learning models have proven to be more effective in improving children's motor skills than conventional learning models. The activities carried out on nature-based learning models actually provide new experiences for children's motor activities such as making crafts, constructing buildings, using toys, doing outdoor games and outdoor sports. This is because in the PBA Model there is an attraction and process that is able to accommodate the child's learning characteristics. In addition, the PBA Model is a learning model that has the principle of learning about nature, learning by using nature, and learning with nature. Activities in learning PBA models emphasize the freedom of children to choose activities based on the desires and interests of children. These activities involve all the limbs and the five senses of the child so that the child's development process can occur more quickly and optimally. Naturebased learning models can also be used as material for further research to develop aspects of child development such as cognitive, language, art, and social emotional.

\section{ACKNOWLEDGMENT}

Special thanks to the beloved campus of Yogyakarta State University and the Postgraduate Program which have been very helpful in supporting the completion of this article. Do not forget the many thank you for the thesis supervisor, namely the Sutapa Stage, who guided the author to the completion of this article. The last article this author presents to both parents is the biggest inspiration in all things.

\section{REFERENCES}

Alim, M. L. (2015). Upaya Meningkatkan Kemampuan Fisik Motorik Kasar Anak Melalui Kegiatan Melambungkan dan Menangkap dengan Berbagai Media Anak Usia Dini Di TK Al- Fajar Pekanbaru, 8393. 
182 | The Implementation of Nature-based Learning Models to Improve Children's Motor Skills

Anderson-McNamee, J. K. M. E. F. and C., \& Science Agent, Cascade County, and S. J. B. (2010). The Importance of Play in Early Childhood Development MontGuide.

Bodrova, E., \& Leong, D. J. (2013). Play and Self-Regulation, essons from 6ygotsky s, 6(1), 111-123.

Castetbon, K., \& Andreyeva, T. (2012). Obesity and motor skills among 4 to 6-year-old children in the united states: nationally- representative surveys.

Dolya, G. (2009). Vygotsky in Action in the Early Years The ' Key to Learning ' curriculum.

Dwirahmah, E. (2013). PAUD PPs Universitas Negeri Jakarta lembaga pendidikan , baik pendidikan formal pendidikan non diamanatkan oleh diberbagai keberhasilan di masa depan ". Hal muda , bahwa secara alami dilaksanakan dengan cara bermain.

Huang, R. (2003). What Can ChildrenLearn Through Play? Chinese Parents' Perspective of Play and Learning in Early Childhood Education, 12-19.

Iivonen, S., \& Sääkslahti, A. K. (2013). Early Child Development and Care Preschool children's fundamental motor skills : a review of significant determinants. Early Child Development and Care, O(0), 1-20. https://doi.org/10.1080/03004430.201 3.837897

Jackman, H., Beaver, N., \& Wyatt, S. (2014). Early education curriculum: A child's connection to the world. Cengage Learning.

Miller, R. (1996). The developmentally appropriate inclusive classroom in early education. Delmar Publishers.

Moore, R. C., \& Cooper, A. (2014). Nature Play \& Learning Places.

National Association for the Education of Young Childhren (NAEYC). (2009). Developmentallty appropriate practice in early childhood programs serving children from birth trough age 8: A position statetmen of the
National Association for the Education of Youg Children.

Ridgway, A., \& Quinones, G. (2012). How do Early Childhood Students Conceptualize Play-Based Curriculum ?, 37(12).

Samuelsson, I. P., Carlsson, M. A., Samuelsson, I. P., \& Carlsson, M. A. (2008). The Playing Learning Child: Towards a pedagogy of early childhood The Playing Learning Child : Towards a pedagogy of early childhood, 3831. https://doi.org/10.1080/00313830802 497265

Silberman, Mel. (2009). Active Learning 101 Strategi Pembelajaran Aktif. Yogykarta: Pustaka Insan Madani.

Sujiono, Bambang. (2010). Bermain Kreatif Berbasis Kecerdasan Jamak. Jakarta: Indeks.

Sujiono, Yuliani Nurani, Tampiomas, Clony, dan Syamslatin, Evira. (2007). Metode Pengembangan Kognitif, Jakarta: Universitas Terbuka

Wiliam, D. (2010). The role of formative assessment in effective learning environments. The nature of learning: Using research to inspire practice, $135-155$.

Wulansari, B. Y., \& Sugito. (2016). Pengembangan model pembelajaran berbasis alam untuk meningkatkan kualitas proses belajaranak usia dini. Jurnal Pendidikan Dan Pemberdayaan Masyarakat, 3, 16-27.

Yusnira. (2015). Pengelolaan Pembelajaran melalui Bermain Pasir Dan Air Pada Sentra Bahan Alam di PAUD Insan Kamil Bangkinang Kampar, 1, 161168.

Zurek, A., \& Torquati, J. (2014). Scaffolding as a Tool for Environmental Education in Early Childhood, 2(1), 27-57. 